\title{
3
}

\section{Jean-Jacques Rousseau and the Discourse of the Exotic}

\begin{abstract}
In order to elaborate notions of national and cultural identity, the new American nations could draw on accounts of discovery and conquest as rich sources of images and information, but in most cases they did not go straight to those accounts. Instead, they turned to cultural artifacts from contemporary European art and thought, to romanticism and political theory as elaborated in eighteenth-century England and France. These European theories, as a matter of course, used information from the Americas, by then incorporated into a discourse of justification of European conditions or opposition to them. This interaction between American images and European concepts can be traced in many ways, but since Jean-Jacques Rousseau's works articulate many of the terms in which the American struggle for independence was formulated and codify important aspects of the transposition of a discourse of otherness into European politics, especially in hypotheses about the origin of political and social organization, they can be examined as representative of that interaction.

Rousseau's influence on the language and thought of the eighteenth and early nineteenth centuries was so pervasive that it is hard to pinpoint. At the same time, his thought is so steeped in the intellectual cross-currents of his time that he can also be seen as a spokesman, and "influence" seems the wrong term for the endless ripples created by
\end{abstract}


his writings. His work gave intellectual weight and general currency to a system of terms that, like the term "discourse" in our time, escaped its first user's control, acquired its own meanings and value, and infiltrated the languages of politics, economics, morals, and literature. ${ }^{1}$ Even at a quick glance, accounts of his influence appear as likely to list those who attacked him as those who followed him, and his ideas spread despite intense private and official opposition and despite the banning and burning of his books. Du contrat social, published in Amsterdam in 1762, was immediately both forbidden and pirated in France; it was banned in Geneva, after it had about a dozen editions between 1762 and $1763 .{ }^{2}$ Emile was burned in Holland, Paris, and Geneva; in 1762 it was placed on the Catholic index of forbidden books, and Rousseau was forced to flee Paris and shun Geneva. ${ }^{3}$ Nevertheless, the book became the most influential treatise on education in France and left its mark on theories of education in Germany and in England, where it was translated at least twice despite English dismay at the French Revolution, for which Rousseau was counted at least partly responsible. ${ }^{4}$ Just as his writings were credited with inspiring political positions from the extremes of totalitarianism to anarchy, so they were refuted at the beginning of the nineteenth century by traditionalists such as the vicomte de Bonald, or liberals such as Benjamin Constant, positivists such as Auguste Comte, or socialists such as Pierre Proudhon, serving as a stimulus for dissent and for discussion and debate where they did not serve as inspiration (Robert Derathé, "Les réfutations du Contrat social," p. 9o). In Spain although Rousseau's friends met regularly to study his works despite prohibitions by church and state, one of the main instruments for the dissemination of his ideas was the heated refutation

${ }^{1}$ Jacques Derrida makes a complicated case for Rousseau's role in the establishment of the very notion that is now called "discourse," its sign-centeredness, its selfreflexiveness, its dependence on a sense of "desire," and its concomitant-as it is put in German-Bodenlosigkeit (see "Introduction to the 'Age of Rousseau,'" in Of Grammatology). There is an implicit claim of discursive synchronicity in Derrida's analysis, as if he were talking with Rousseau rather than about him from a distance of the two centuries in which political developments and scholarly commentaries have affected the semantic context and content of Rousseau's writings. I do not aim at this synchronic effect, but it confirms the sense that Rousseau pervades (and many still say that he perverts) even our thought.

${ }^{2}$ See Ronald Grimsley, Introduction to Rousseau, Du contrat social, pp. 3-5.

${ }^{3}$ Maurice Cranston depicts the Geneva in which Rousseau grew up as stern in morals but relatively free in ideas (Jean-Jacques, chap. 1, esp. p. 27): the banning of his works there is a strong indication of the shock they provoked.

${ }^{4}$ François and Pierre Richard, Introduction to Jean-Jacques Rousseau, Emile, ou De l'Éducation, pp. xxix, xxx. 
of his Discours sur l'origine et les fondements de l'inégalité by Benito Feijoo de Montenegro (Jefferson Rea Spell, Rousseau in the Spanish World, pp. 45, 20-22). In Argentina, on the other shore of the Atlantic, the Colegio Carolino offered a whole course to combat Rousseau's ideas, ensuring that at least some version of them would be available to impressionable young minds (Boleslao Levin, Rousseau y la independencia, p. 24).

Rousseau's works became central to Enlightenment discussions of liberty, equality, political representation, and property from which the European colonies in the Americas derived theoretical and moral justification when, one after another, they began to declare their independence. The effect of his thought was not always direct, just as the intellectual and political processes leading to independence were not uniform throughout the hemisphere. Unlike the former French and Iberian colonies, the United States received French political theories in part indirectly, through the debate in England which blunted their radical edge; as the first to achieve independence, moreover, the United States itself became a model for revolutionary movements on both sides of the Atlantic. Brazil, unlike all other former colonies, won independence as a monarchy. One can trace the influence of both the French Enlightenment and the theorists of American independence in its earlier insurrections, particularly those of 1789 in the provinces of Bahia and Minas, which did demand national independence in terms of European and U.S. ideas of social and economic justice derived either directly or through their detractors and interpreters from Rousseau, Guillaume Raynal, and Gabriel Bonnot de Mably. ${ }^{5}$ By the time the nation

${ }^{5} \mathrm{E}$. Bradford Burns, in A History of Brazil, chap. 3, traces the development of intellectual justifications for independence: improvements in schools brought about by the marquess of Pombal's expulsion of the Jesuits; the founding of academies dedicated in particular to the study of European and North American scientific and political ideas; the kinds and quantities of books imported (he notes the emphasis on learning foreign languages and the visits of foreign intellectuals for lecture tours and study periods as instrumental in establishing direct contact between Brazilian intellectuals and foreign-mainly French and German-ideas). He notes that leaders of independence movements owned copies of the American Declaration of Independence and of works by Thomas Jefferson and Thomas Paine. Kenneth R. Maxwell, documents a meeting at Montpellier between Jefferson and some Brazilian students at the university desirous of Brazilian independence ("The Generation of the 1790s," p. 107). He also remarks on the books by and about figures of the French Enlightenment and the North American independence theorists to be found in the libraries of the Minas conspirators. Court documents listing books confiscated from the conspirators also indicate that those intellectuals who defined the aims of Brazilian movements of independence had found inspiration in the French thinkers of before the French Revolution. Eduardo Frieiro discusses one such list of confiscated books, which is 
adopted a republican government, almost a century later, it did so in the vocabulary of positivism; it is in the effects of the second emperor's francophilia, as well as in his interest in the United States, that one finds the mark of Rousseauean ideas. ${ }^{6}$ In Mexico, by contrast, portions of $D u$ contrat social found their way into constitutional drafts. ${ }^{7}$ In general, as Horst Dippel shows, the formulation of early modern concepts of the state, of the place and origin of laws, of the possibility of different forms of property ownership, of the formation of national wealth, of the relation between the individual and the state, which were essential in the establishment of the new American nations, arose amid an intense interchange of ideas between English and French thinkers to which the United States contributed intellectually and also by functioning as a kind of socioeconomic laboratory. ${ }^{8}$

The degree to which Rousseau's thought affected various American movements for independence is a politically charged question; it is also

also a snapshot of the intellectual climate in Ouro Preto, capital of the province of Minas Gerais, at the time of the 1789 insurrection, known as the Inconfidencia $(O$ diabo na livraria do Cônego). Kátia M. de Queiroz Mattoso finds key concepts from important speeches of the French Revolution in pamphlets and posters of the uprising in Bahia (Presença francesa no movimento democrático baiano de 1798). Given the paucity of the documentation-three lists of books resulting from the government's investigation of the movement and a number of pamphlets that had been posted in prominent places around Salvador-and the difference in conditions between prerevolutionary France and colonial Bahia, however, the data point to the use of a vocabulary of the French revolution to lend legitimacy to the Bahian rebels, rather than an influence of French political events upon the dynamics of the Brazilian uprising. David Haberly, "The Mystery of the Bailiff's List, or What Fagundes Varela Read," illustrates that foreign books were common in Brazilian libraries, but also that intellectual influence is serendipitous, quite likely to give equal weight to works by authors we now consider most important and others now sunk in complete-and presumably deservedobscurity. The necessary assumption, if one wants to explore the influence of ideas on political movements, is that the "great" authors exercised an ineffable force that impressed itself on lesser luminaries who ended up as something like "carriers" of their ideas.

${ }^{6}$ Thomas Skidmore, in Black into White, documents the persistent cultural influence of France over Brazil, even into the twentieth century, and the effects of positivism on both abolitionism and republicanism. See esp. chaps. 1-3. He documents the emperor's interests in "Brazil's American Illusion: From Dom Pedro II to the Coup of 1964," esp. p. 73.

${ }^{7}$ The essays collected by Mario de la Cueva in Presencia de Rousseau trace the influence of Rousseau on the independence movements of Argentina, Mexico, Colombia, etc. ${ }^{8}$ See Horst Dippel, Individuum und Gesellschaft, esp. chap. 3. David Cameron's thesis of the comparability of Rousseau's thought to Edmund Burke's rests on a more general view of an intense interchange of ideas between England and France in the second half of the eighteenth century. See specifically The Social Thought of Rousseau and Burke, p. 36. 
unnecessary to answer. The purpose of the present discussion is to examine how Rousseau's vocabulary of origins, legitimacy, and opposition to established power structures was used to justify the American nations' political separation from the European metropoles and to define their separate national identities. I also want to investigate the degree to which Rousseau's vocabulary is itself constructed from elements furnished by Europe's experience of the American exotic. When the new nations began to work seriously at affirming cultural independence and defining national identity, Rousseau's writings furnished some of the necessary concepts and vocabulary. There, Rousseau's influence was once more pervasive and less direct than in the political arena, operating on the formulation of concepts of national identity through a European view of the Americas, traceable in his use of American elements at the foundation of his arguments.

The Discours sur l'origine et les fondements de l'inégalité repeatedly refers to American examples as it theorizes the origins of society and of humanity; the terms of these references illustrate the characteristics accorded to "Americans" and fix them in the discourse about the Americas. They recur in $\mathrm{Du}$ contrat social, which uses Amerindians as examples of presocial man and which influenced the wording of new constitutions in South and Central America; in Emile, which provided the basis for a rationally planned system of education to produce appropriate citizens for the new republics, and in La nouvelle Héloïse, which not only defined the proper place of the domestic sphere in the economy of the state but also, together with the second part of Emile, proposed a proper assignment of functional and psychological roles to men and women, husbands and wives, so as to constitute the family as the breeding ground of a sturdy citizenry. Thus, the examples Rousseau adduces from what was known of so-called primitives constitute themselves into a language of opposition to European social structures which is grounded in the societies of the New World and later shapes their image. Its terms, however, escape any determination of accuracy or truth. They are exempted, on one hand, because of the scandal of opposition and, on the other, because of the familiarity conferred by centuries of repetition. Rousseau's ideas may be questioned but not his "Americans"; noble or brutish, they persuade, embedded in a common knowledge careless of contradictions.

Of course, the language that here presents as "roles" the positions of male and female, weak and powerful, child and well-intentioned adult, citizen and outsider, is foreign to the system of Rousseau's 
thought. Nor are exoticism and power part of a Rousseauean vocabulary. I use these concepts to estrange Rousseau's discourse in order to weigh the consequences of its acceptance into the vocabulary with which new polities were established and with which they defended the legitimacy of the redistribution of power effected through independence and nation formation-events contemporaneous with the violent redistributions of power within Europe at the end of the eighteenth century.

I am interested here not in how Rousseau shaped a discourse of the creation of the state but in the echo of Rousseau-something like the harmonics his concepts provide to the tone of his times, that which is recognized as Rousseauean. It is not the structure of Rousseau's arguments that I address but their effects, acknowledged even among his fiercest detractors in the conviction that his ideas led to action, to the establishment of structures of government, courses of study, attitudes toward authority, and most important here, concepts of the relation between past and present, politics and history, class and education which informed the discourse of the New World.

Rousseau never wrote specifically about the Americas; he was not interested in the politics or the anthropology of non-European states and peoples, and he did not contribute to the literature of the exotic that flourished in the middle of the eighteenth century. ${ }^{9}$ In Frêle bonheur, Todorov hints that Rousseau was uninterested in otherness because he was too absorbed in constructing a personal and cultural self. ${ }^{10}$ But it is precisely because his works are not about the exotic that they show its acculturation so clearly: they use the exotic as a given.

Rousseau illustrates theoretical assertions about human nature and the conduct of politics by frequent reference to accounts of the New World. In the seventeenth century, notes Hans Günter Funke, particularly in France, these accounts had "fused the traditions of the Renaissance utopia and the authentic travel report" to create a widely read genre that used observations about real or fictive non-European lands and peoples to criticize European mores and societies. These alternative perfect societies were presented with all the discursive markers of truth; formally, they were not to be distinguished from the travel accounts

\footnotetext{
${ }^{9}$ In Tristes tropiques Lévi-Strauss calls Rousseau the most ethnographic of all the philosophers but refers only to his extensive use of ethnographic accounts available at the time, acknowledging his lack of any firsthand experience of cultural otherness (p. 451).

${ }^{10}$ Frêle bonheur examines the causes and consequences of viewing Rousseau as a pioneer in the exploration of the self.
} 
circulating since the discoveries (Funke, Die Utopie der französischen Aufklärung, p. 42). ${ }^{11}$ The otherness of the New World was thus quite consciously made to occupy an intermediary space between truth and fiction, and it became available as a formal tool for social criticism and political speculation. As Rousseau wrote, this transitional function of the discourse of otherness had been deeply absorbed into the literature of criticism; it did not necessarily mark a difference. Rousseau's predecessors had buttressed theories about the origin of society or property with examples from the new worlds, just as they had attributed to foreign visitors or captives in Europe an outsiders' perspective from which to discuss and criticize aspects of European politics and mores. Montesquieu's Lettres persanes exemplifies such a use of the outsiders' perspective, as does Swift's device of sending his hero to outrageously "exotic" places for a clearer view of what was amiss in England. But Rousseau's use of the exotic marks a further development. Hottentots, Caribs, and Hurons figure in his arguments about the origin of humanity and society as ancestral figures, remnants of what Europeans must have been sometime in the past. They become the evidence in a protoevolutionary discourse not as objects of astonishment or fear, as in the writings of the explorers, settlers, and scientists, or of admiration, as in the utopias, but as providing something like the historical equivalent of introspection. ${ }^{12}$ Primitives are thus englobed in the European self, made into illustrations not of what is alien to Rousseau's civilized readers but of what they ought to recognize as existing vestigially in themselves. Primitives illustrate the past and explain the present; in a corollary, they give hope for the future.

This is Rousseau's imprint on the discourse of the exotic. It became a validation and a rejection of European civilization, axiom and argument

\footnotetext{
${ }^{11}$ Funke's aim is to define the Enlightenment utopia in terms of genre; some of his observations are suggestive in other contexts too. For instance, unlike the utopian writings of classical antiquity or the Renaissance, which take the form of dialogues, those of the Enlightenment are most often travelogues. They operate a shift from the encounter with another self to an encounter with an other (p. 41).

${ }^{12}$ Arthur O. Lovejoy notes that Rousseau's originality does not lie in his treatment of the "state of nature" as such, which owed much to thinkers such as Samuel von Pufendorf or even Denis Diderot, but in his "early formulation and diffusion of an evolutionary conception of human history" ("The Supposed Primitivism of Rousseau's Discourse on Inequality," p. 25). Bernard Gagnebin and Marcel Raymond, editors of the Gallimard edition of Jean-Jacques Rousseau, Oeuvres completes, compile a long list of sources for Rousseau's notion of the primitive, including travelers and other philosophers, and comment on his importance as a protoevolutionarist (Discours sur l'inégalité, pp. 1304-5).
} 
about the foundations of society, actively debated blueprint for the establishment of new non-or counter-European polities, and quietly accepted characterization of the human substratum of these polities-a realized language and virtual grammar. Thus Rousseau's definition of something like a zero degree of human social and political organization embodied in the American exotic justifies claims of legitimacy based on the correct application of the first principles he deduces. Antipathy to Rousseau as one of the ideologues of the French Revolution did not prevent acceptance of the idea that it is possible to deduce the moment before the origin of social and political organization and return to it to choose a new form of community.

Searching for the origins of legitimate political power, Rousseau speaks not only to opponents and reformers of contemporary regimes but also to preservers of the state. Thus, as the American colonies declared themselves independent of European metropoles and sought, on one hand, to legitimate their rebellion against the colonial powers and claim recognition in the concert of nations and, on the other, to write the rules of law within their borders, Rousseau's theoretical exposition of society could be referred to as a blueprint. Not that Rousseau's were the only ideas then current and influential; they coexist in a passionate dialogue with and against Locke, Hobbes, Montesquieu, and Voltaire. But insofar as Rousseau proposed the systematic constitution of a new form of social organization, rather than an analysis of the existing one, he presided over the establishment of a discourse of independence even more than over the establishment of the particular articles that legally founded that independence. Though his influence was muted in the United States, possibly because of the articulate opposition to his ideas in England, Rousseau left his imprint indirectly. Henri Roddier shows that in England Rousseau's ideas permeated the arguments about the power of government and the role of the people's will in the various crises of George III's reign, and that they continued to worry the English as they formulated their reaction to the French Revolution and constructed a national educational policy (see Rousseau en Angleterre, esp. chap. 6). As frameworks for ideology and policy, these debates in turn affected American political thought before and after independence. At the same time, the American discourse of opposition to metropolitan power and of difference from the metropolis used the terms of a European discourse of opposition in which the original inhabitants of the Americas figured as difference. Appropriating that discourse, the new nations reincorporated into their definition of nationality a European 
definition of their difference, filtered through the ideas of a European proponent of opposition to contemporary forms of power distribution in Europe.

But Rousseau's primary importance for the establishment of a discourse of the American exotic is his incorporation in his theory of the origins of social organization of a theory of the ontogenesis of man: the "natural man" he posited, this "savage," was mostly American. Rousseau's construct drew on knowledge current at his time, and his arguments were acceptable within the expanding language of intellectual and then political opposition to established power. Thus, even though many of his readers and the authorities of church and state found his conclusions disagreeable, his works could nevertheless become the basis of both political opposition and intellectual respectability, both identity and difference, origin and future, in the more nebulous reign of a discourse of national consciousness. The traces of his thinking are found not only in political discourse but also in the discourses of identity, nature, and history by means of which the new nations claimed cultural autonomy. Whether Rousseau reached the New World directly through his books, indirectly through his detractors, or even once more removed, through the debates around his ideas, the traffic marks a new phase in the exchange by which American raw materials-goods or concepts-came back to be reintegrated in national cultural or political economies.

The materials that inform a discourse do not determine its import, however. In the seventeenth century Europeans fused American material into the form of the pastoral golden age and noble savage, on one hand, and the antipastoral figure of the "wild man," on the other. ${ }^{13}$ In the eighteenth century Rousseau's works gave rise to both a "romanticizing" and a politically oriented view of the aboriginal populations of non-European lands in general and the Americas in particular. The romanticized Americas appeared as apolitical repositories of the moral virtues and physical endowments that European civilization (identified with civilization as such) had lost. The political America was the laboratory where a new political order would be created under known and controlled circumstances. There the promise of $\mathrm{Du}$ contrat social could be fulfilled, legitimating the writing of all the "social contracts" that affirmed the independence of American states, any or all of which

${ }^{13}$ Peter Weston, in "The Noble Primitive as Bourgeois Subject," notes the various uses and transformations in European cultural history, of the notion of primitive man, derived from accounts of the New World (see esp. pp. 60, 61, 65). 
might realize Rousseau's dream, overcoming both the primitivism of savages and the corruption of civilized Europe.

Critical of established political authority and privileging the point of origin of social organization, Rousseau's terms were used to justify the transfer of established power from the metropolis to the new nations and to legitimate new power relations. But the same new nations became uncomfortable with these same terms when they found themselves striving for acceptance among established countries. As the literature of the new American nations set for itself the aim to complement political with cultural independence, the echoes of Rousseau in the discourse of the New World changed: his language was used less for political purposes than to elaborate a concept of nature identified with the Americas, for with that identification, his language established, at the origin of the new nations, a substratum and guarantee of virtue, a corrective against the cultural pressure of a (European) civilization that had evolved crookedly from just such origins. This notion of nature separated the Americas from the politics of the European states, no longer "natural" in the sense of divinely ordained and uniquely fitting within the proper order of the world. Nature now preceded and opposed social organization; though it included some essentially human qualities, it excluded products of human activity. The original inhabitants of the New World, then, dwelled in a realm of nature from which Europeans had fallen away in the course of their history. In this reading of Rousseau, New World otherness is no longer defined in political terms; it is characterized not by its potentially redeeming historical function but by the fortunate absence of history. ${ }^{14}$ Thus the New World can turn the charge that it lacks history against the Old World and at the same time justify its claim to its own, redemptive historical weight.

But a discourse on otherness is always in some way adversarial, so that the new nations' claims to historical depth and to the role of redeemers of a botched European history are not necessarily taken seriously. Europe never devalues its own sense of historical weight; if it accepts the notion of a redemptive primitivism, it is only to make opposition confirm the weight of its history. Marie Antoinette valued her pastoral theater, and the crowds that came to the reconstruction of a jungle scene in Rouen were delighted with the opportunity to meet

${ }^{14}$ Bronislaw Baczko, Rousseau: Solitude et communauté, traces Rousseau's notions of history and otherness to an existential crisis generated by his alienation from the society of his time, which he made many attempts to describe and theorize. 
face-to-painted-face with what they regarded as nature, but neither the queen nor the crowds made their homes in these representations of a world more innocent than their own. These theatrical constructions derived their value from being framed by a city and a palace, themselves the scenes of real history and real power. Nature unframed, as in the Americas, continued to be only an invitation to intervention, and the literatures of the Americas still struggle now, as they did more clearly at the origin of the American states, with the problem of preserving the values of the natural, which had at first defined their independence, while claiming the legitimacy of history, which would protect them.

The positive value Rousseau gives both the original substratum of nature and the creation of a legitimate structure of government and social organization promised to solve the dilemma of ahistorical legitimacy. His work allowed the new nations to define themselves as embodying the virtues either of nature or of a new state, as opposing the corrupt society of contemporary Europe or exemplifying progress from the insufficiencies of primitivism to the fulfillment of a state of civilization that Europe had been unable to achieve.

In time the first part of his argument, proposing a return to origins in nature, overwhelmed the second part, which operates the transition from nature to civilization. When that happened, the new nations had to buttress their claim for cultural parity by denying their "lack of history," a lack that implies crude, rather than virtuous and uncorrupted primitivism. The link with Rousseau, useful for a while, was repressed. It emerges in occasional movements back to nature or in attempts to rediscover a Native American past, often colored by the contradictory desires to deny history and to assert historical depth, to atone, if that past is covaluable with that of Europe, for its destruction. Then the new nations were forced to digest their contradictory heritage as "native" and destroyers of "the natives."

It is for his concept of the "noble savage" that Rousseau is most commonly associated with a New World discourse of cultural independence. Like many shorthand terms, this one is neither clearly defined nor easy to find in that precise form in its author's writings. But its very imprecision expands its meaning and creates a good feeling of understanding between interlocutors before the rigors of definition set in.

The idea of the nobility of the American native did not originate with Rousseau; ${ }^{15}$ it was part of the repertoire of attributes assigned to the

${ }^{15}$ Lévi-Strauss attributes its formulation to Diderot, stressing that "Rousseau never fell into Diderot's error of idealizing natural man" (Tristes tropiques, p. 451). 
peoples of the new lands from the earliest days of conquest. One could argue, as Todorov has for those days, that a characterization of the savage as noble is as likely to arise from ignorance, misunderstanding, and lack of imagination as the picture of that same savage as cruel and treacherous (Conquête, chaps. 1, 3), but since it was not the aim of the more benign characterization to justify political domination and social intervention, it acquired an aura of innocence and impartiality which made it seem an appropriate vehicle for the American claim to a positive otherness.

Thus the noble savage entered a system of arguments and, misinterpreted, became an aim of desire (Baczko, p. 137); the concept's adaequatio ad rem became less important than its role in that system of arguments, as one can see in Claude Lévi-Strauss's assertion that "the study of these savages . . . helps us to build a theoretical model of human society, which does not correspond to any observable reality," and in his assessment of the usefulness of such otherness: "Other societies" provide us with "a means of distancing ourselves from our own" (Tristes tropiques, p. 453). As for Rousseau, he relegates primitive man to footnotes, where primitivism founds a potentiality, a predisposition in the very nature of humankind strong enough to carry philosophical statements about authority and about the relation between individuals and the social system in which they exist. The "nobility" of this original human being is a function not of his obedience to moral rules but of his potential to create and obey them. ${ }^{16}$ The noble savage is not yet virtuous and does not yet live either in society or in history but is capable, as he falls into history, of creating a virtuous society ${ }^{17}$-the process of forming a society constituting, in an analogy Rousseau did not seem able to avoid, something like a fall. In raising radical questions about and voicing radical objections to the governments of this time and the societies over which they presided, however, Rousseau is not addressing only a particular political organization. Combining the political and the psychological, one can also argue, with Bronislaw Baczko, that Rousseau was driven to radical criticism of his society because he saw it as entirely alienating and alienated, so that, for the health of its

${ }^{16} \mathrm{My}$ consistent use of masculine nouns and pronouns accords with Rousseau's usage rather than with present rules of gender neutrality in public expression.

${ }^{17}$ This potentiality is what Rousseau calls perfectibilité, a distinguishing characteristic of humanity, which, it must be remembered, implies a positive valuation of the social state and also the ability to decay to a negatively valued state (Discours, p. 142); decay could turn the citizen of a good society into the accomplice of a corrupt one, like that which Rousseau criticizes in the Discours as well as in La nouvelle Héloise and Emile. 
members, it had to be rebuilt from first principles. To help himself and his readers imagine a human being not yet alienated by the fall into history which produced that corrupt civil society, Rousseau refers, in comments scattered throughout the Discours sur l'inégalité, Du contrat social, and Emile, to the common and readily available stock of varied information about the "savages" of the New World.

But that corrupting history is what Europe wrote and, in due course, imposed on the Americas; it conditions the Western imagination. Rousseau's attempt to go back to origins is an attempt to unimagine Western history and, thus, is productively contradictory at its inception. ${ }^{18}$ It hovers between imprisonment in the language in which it must be spoken and a free fall into the emptiness that separates the noble savage from the Indian of the Americas. The "emptiness" of the Americas, in all its factual inaccuracy and cultural suggestiveness is yet again metaphorically extended to its original inhabitants, still outside of systematically organized societies and devoid of history and once again made ready for the intervention of forces that create history. If emptiness was necessary for the European conquerors to justify their intervention and their possession of the land and souls of their inhabitants, it was reasserted by the creators of the independent political entities of the New World. The Rousseauean reformulation of American emptiness gave credence to their claim that they were creating societies anew. Although historical depth was sometimes asserted by including the Amerindian past, moral legitimacy tended to be justified by claiming structurally conditioned virtue rather than by accepting the authority of historical continuity. Thus the claim to the right of rebellion stated in the U.S. Declaration of Independence, which applies criteria of extrahistorical right to a political problem, justifies the transfer of power by a break with history and from a point of judgment outside history. ${ }^{19}$

${ }^{18}$ The notion of the fundamentally paradoxical nature of Rousseau's thought has been productive in recent criticism. In particular Felicity Baker, in "La route contraire," considers the paradox at the beginning of Du contrat social ("one will force him to be

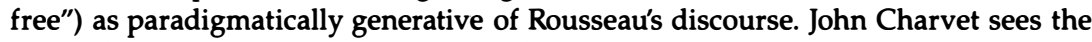
same characteristic but, less tolerant than Baker, judges that Rousseau meant to "return to nature in the sense of refounding society on nature and this project creates a paradox which lies at the center of Rousseau's ultimate incoherence," destroying the credibility of whatever else he has to say (The Social Problem, p. 2).

${ }^{19}$ Henry Steele Commager considers that one of the defining characteristics of American law is its reliance on a system of values above those that institute it, present from the beginning and as useful for the organization of the American state as for its initial struggle with England ("Constitutional History and the Higher Law," in In Search of a Usable Past, pp. 28-55). 
Rousseauean thought appears, then, at the center of the transatlantic debate on history, precisely because, as Baczko points out, Rousseau himself is not a historian, having left no account of a historical period and having shown himself to be as ignorant and fanciful in his discussion of Greeks and Romans (p. 106) as in his views of Hurons. Because Rousseau does not write history, it is possible to disconnect origins from history, to affirm historical depth independent of chronology or the succession of historical facts. Thus the European argument against American cultural parity-namely, that the new nations have nothing to look back on which was not provided by Europe-can be countered by finding in the Americas, where history is beginning again, autochthonous structures and sequences noncontemporaneously analogous to European historical developments.

Since they need not be "historical," Rousseau's American primitives are never completely defined: at times they are the Indians, at times the European settlers. All are reduced to the homey, shocking, or amusing details of intelligible human lives and common human abilities, allowing Rousseau to give form and habitation to what he himself denies has historical truth, in a curious game of hide-and-seek with his sources. The primitive he invents does, however, combine the integrating function of model and the estranging function of critic; it is an otherness that makes imaginable a way of being that is human and yet structurally different from all that his readers commonly think of as human. At the same time and inevitably, this creation contradicts its premises by participating in the structures of contemporary imagination. It is like the partly adolescent and partly mystical attempt to "think of nothing": the structures of ordinary thought and imagination invade the attempted nothingness. In other words, the travelers' account provide Rousseau with welcome signifiers for the central signification of his criticism of society, opposing and comforting his alienation with a vision of integrated otherness. And since signifier and signified are not separable, Rousseau's theoretical construct absorbs the available images of the New World as emptiness and potentiality and also transforms them into a useful otherness that can reoriginate the culture in which its concept arose.

Perhaps because it is difficult to imagine and to express in intelligible terms the true otherness of a nonsocial man, the image of New World "savages" is not consistent throughout Rousseau's work. In the Discours and in $\mathrm{Du}$ contrat social they live in an exemplary closeness to nature original to man and lost to Europeans, but in the justly forgotten play 
La découverte du nouveau-monde the original Americans are akin to the Romans, Greeks, or Spaniards of French classical theater and suffer the same exasperations of love, honor, spite, and jealousy, though stripped of classical fullness and reduced to the allegories of an age that no longer believes in them. At the end of the play an "American" declares, "No heart is savage that is conquered by love"; Columbus tells the Indian chief, "I want you for a friend, be Isabella's subject"; a Spanish lady sings, "Discovering new worlds is offering new myrtles to Love"; and the chorus concludes, "Let us spread over the universe / Our treasures and bounty. / Let us unite, in our Alliance / Two worlds separated by the abyss of the Ocean." The contrast between the classically noble Americans of the play and the keen-nosed Canadians of the political writings shows not only the contradictions between the various images of the original inhabitants of the New World but also the kinship between the concepts of a nobility homologous to that of a braver European past and of a virtue dependent on its distance from the foundations of present European civilization. In one passage of the Discours sur l'inégalité, Rousseau seems to bridge the opposition between primitive and ancient, so marked in his play, by making it into a question of misreading: noting that ancient reporters never speak of orangutans or mandrills, he muses that perhaps those were what the ancients called satyrs or fauns, seeing gods where modern man sees only beasts (p. 211).

This oscillation between considering the original inhabitants of the New World as primitives, precivilized tabulae rasae, and considering them as ancients, carriers of human and civic virtues long lost to Europeans, appears in their definition by Europeans as well as in the first American writings on them; it is one of the many traits imported from European discourse on the New World which are used to distinguish the New World from Europe. Like other transposed elements of European discourse about the Americas, it both classifies and evaluates. It is useful that savages can be called upon to represent a desired American difference, while they also, as ancestors, stand at the origin of identity in European civilization; it is possible through them to articulate the equivalence in value of the humanity underlying all differences. At this point also, the universalizing tendency of eighteenth-century philosophical theories coincides with universalizing tendencies in the Christian churches and works to justify the changes imposed on the New World and its original inhabitants by the process of settlement. The explanatory usefulness of these ancestral, primitive, ahistorical, inno- 
cent, virtuous, and ultimately abstract Indians is independent of their or their cultures' continued existence: they would serve it as well by becoming civilized or by ceasing to exist. It is only later that romantic nostalgia would demand a different kind of authenticity for the recognition of the savage's otherness, would claim that once again the Roman virtues were about to disappear.

But Rousseau's use of American Indians is teleologically if not always semantically consistent: his Indians are an important part of his didactic project. Rousseau's reconstruction of the world takes for granted an already established tradition of the savage as critic. Anthony Pagden catalogs works widely read, widely respected, or both, which created the composite image of natural man to which Rousseau could refer without need for further definition and without fear of being mistaken. He notes that although "the savage comes always from a [remote] world, . . . if the normative values which he embodies are to be acceptable or indeed intelligible to the reader, his moral universe must in all important respects be a familiar one" ("The Savage Critic," p. 33). ${ }^{20}$ This familiarity of the moral universe finally absorbs the remoteness of the "savage" world; discourse regularizes experience and tames otherness. Nevertheless, the disjunction operated by a discourse that criticizes European mores from the "outside" reinstitutes difference, forcing an imaginative estrangement of custom and belief, showing a rift between them, destroying the illusion-only then discovered to be such-of their seamlessness. In his role as critic of European society, the savage makes it possible to say, like Pagden, that Christianity and European laws result from the work of imagination; they distort reality and displace reason (p. 41). But it must be remembered that the possibility of this critical formulation also depends on rifts within Christianity and widespread opposition to certain forms of European law. The notion of a

\footnotetext{
${ }^{20}$ Pagden's list of works in many languages attests to the diffusion of these notions of the savage within Europe and to the relatively small role played by national boundaries and language differences in the formation of that image; unlike the variety of images in reports of the encounter, this image seems relatively independent of the particular political and economic conditions of the various colonizing nations or of the scholars, thinkers and writers who examine government, society, morality, the origin of social structures, or the treatment of "savages." The "fictitious Mexicans of Dryden (in The Indian Emperor: or the Conquest of Mexico), Sir William Davenant's Peruvians, the Huron and the Incas of Voltaire, Diderot's Tahitians, Denise Vairasse d'Alais's Australians, the Huron of the Baron de Lahontan," the Arlequin sauvage of François Delisle de la Drévetière, mentioned by Rousseau in "Lettre à d'Alembert," or "Tombo-Chiqui: or the American Savage, of John Cleland," are very much alike "The Savage Critic," p. 33).
} 
"natural reason" with which John Dryden's Moctezuma confutes the priest who visits him while he is on the rack is not alien to European thought; the savage king's arguments are intelligible in reference to it (The Indian Emperor, act 4; see Pagden, p. 35). Thus, a discourse of American national consciousness, if it is to assert difference and achieve intelligibility, must begin by finding the interstices, the faults, in European discourse; the most visible and most easily inhabitable of these faults are already associated with images located in the Americas, in the utopias (or dystopias) to which the discoveries had given a geographical position (cf. Pagden, p. 34).

Examples from the Americas are thus used to inform and to criticize or instruct. The eighteenth-century European discourse of American exoticism mediates between the worlds of facts and of values. In Rousseau facts are subordinate to values; his discourse on values mounts a radical criticism of European society both diachronically, with hypotheses about the origin of societies, and synchronically, with proposals for the reconstruction of the political self. Formed or reformed in accordance with the directives of Rousseauean pedagogy set forth in Emile, that self would want and be able to create a self-sufficient household like that of $L a$ nouvelle Héloise and a civil society like that of $D u$ contrat social. The realms of self, family, and state appear in Rousseau as concentric circles, all based on the well-formed individual, who has acquired proper socialization but not lost primitive virtues and capabilities. In La nouvelle Héloise, this is how Julie describes the organization of M. de Wolmar's household: "The order that he has created in his house is the image of that which reigns in the depths of his soul and seems to imitate, within a small household, the order established in the government of the world. . . . he has ordered its first arrangement so well that at present all works as if by itself, and we enjoy, at the same time order and freedom" (pp. 371-72). ${ }^{21}$ One of the important functions of this rational organization is to perpetuate itself: "One does not marry in order to think exclusively of one another but in order to fulfill jointly the duties of civil life, to govern the house prudently, and to raise children well" (p. 372). In this argument any reference to the primitive or the original seems contained in an ancient European image

${ }^{21}$ Felicity Baker notes how similar the proposed relations between child and physical world as developed in Emile are to those between citizen and social world as developed in $\mathrm{Du}$ contrat social, both built on the paradoxical interdependence of freedom and obedience (pp. 137-38). 
of the garden as the place where divine nature and human order meet in harmony.

Yet even in this entirely European novel and argument, the Americas hover on the periphery as a point of comparison and a place of refuge. When Saint-Preux crosses the ocean to forget Julie, his description of what he sees over there summarizes the ways in which the new lands are imagined and used. They are sign and victim of European greed: "I have seen the shores of Brazil, where Lisbon and London draw their wealth, and where the miserable inhabitants step on gold and diamonds without daring to touch them." Or they are a place where untouched nature affords unfallen man the conditions to live virtuously: "I have seen from afar the land of those so-called giants [the Patagonians], who are outsized only in their courage and whose independence is better assured by their simple and frugal life than by extraordinary stature. I sojourned for three months at a deserted and delightful island, a sweet and touching image of the ancient beauty of nature, which seems confined to the ends of the world for the express purpose of serving as a refuge to persecuted love and innocence" (Saint-Preux to Mme de l'Orbe, letter 3, pp. 412-13). The positively valued land of the Patagonians, free from the strife, confusion, and immorality of the rest of the world, forms a parallel to Julie's peaceful garden of reason; the negatively valued shores of Brazil show the effect of European vices transplanted to the New World. The brief passage bundles together several of the significations clustered around the facts of the New World and assigns them their places in Rousseau's political and moral discourse. Meanwhile, as Saint-Preux finds in the New World "a refuge for persecuted love and innocence," La nouvelle Héloise becomes a precursor of the fictions of Bernadin de Saint-Pierre and Chateaubriand. ${ }^{22}$

In Emile, Rousseau fashions not the society but the person, not the setting but the character who, Baczko says, offers the "suggestion to try again to realize missed possibilities, to transcend the present state of things" (pp. 141-42). The individual's return to origins parallels society's return to origins, envisioned in the political treatises, just as the concept of childhood in Emile parallels their proposed notion of natural man. Peter Weston, linking Rousseau's idea of childhood with the image of

${ }^{22}$ To bolster a different argument-that the Leather-stocking tales "retain sentimental characteristics"-Ines Tetley-Jones documents the knowledge of Rousseau in the United States: "The New Eloisa became, between 1761 and 1764, . . the most widely read novel in the colonies" ("Sentimentalism versus Adventure and Social Engagement," pp. 15, 5). 
an American natural man, contends that in Emile "childhood takes over from Locke's America as the philosophical ground of the myth of the free subject" ("Noble Primitive," pp. 67-68); childhood, nature, America take turns as the empty locations for an innocence that precedes present corruption and originates future virtue. Childhood thus corresponds in the development of the individual to the primitivism of natural man in the development of societies, but it makes intervention more intelligible and more palatable, by justifying it through association with the ideologically respectable process of education which had already served to justify colonization. Emile shows how the children of civilization can be educated into remaining simple and moral so that as adults they can form a new, redeemed society. As it shows how to build a new human being, Emile describes the traits that would make the new citizens of the Americas models of what Europeans might have been had they not been corrupted. It is not exactly proof of these assertions, but it is a nice historical touch that Simón Bolivar, the liberator of Spanish America was brought up by a tutor who used precisely the techniques advocated in Emile. ${ }^{23}$ And it probably helped Benjamin Franklin in his conquest of French society that he was seen, in his simple overcoat, as the embodiment of the sober, straightforward, truthful, able, independent, democratic man Emile would have been. Franklin and the new nation profited from his-probably conscious- embodiment of the image of the virtuous and natural American. Close to nature, protected from the vices of civilization and yet able to correct the shortcomings of the state of nature, he presented a living example of American perfectibility. ${ }^{24}$ Such alluring images shaped the data provided by chroniclers of the New World into a system of values and significations with which Europeans spoke of the New World and which Americans could use or had to fight when they proposed to fashion their own language for their own purposes.

${ }^{23}$ Jefferson Rea Spell discusses Bolívar's childhood under the tutelage of Simón Carreño Rodriguez, who taught him physical endurance before any academic subjects and, just like the tutor in Emile, made him read Robinson Crusoe when the child showed an interest in books (Rousseau in the Spanish World before 1833).

${ }^{24} \mathrm{~A}$. Owen Aldridge notes that in Paris Franklin worked quite consciously "to create the impression that he was a rural philosopher or primitive patriarch" (Franklin and His French Contemporaries, p. 13). He was trading on his abilities in the practical world and on the image of simplicity, virtue, and wisdom which often led to an association of "Americans" not only with the uncorrupted origin of society but also with the ancients who were at the historical origin of contemporary societies. He was seen, says Aldridge, as a modern Socrates (p. 12, citing Hervé, Madame Toussaud's Memories, p. 56). 
As Franklin also understood, the new man (like Emile) is not exceptional: he is the average man of nature prepared to live in society, but he has to be carefully prepared to be natural. For Rousseau the natural is not a given but a theoretical construct; the need for re- and deeducation from birth indicates that the corruption of society starts operating on the individual before consciousness develops. But as one follows Emile from birth and from nature, certain logical (some onto-, and some epistemo-) problems come to the fore from which the warm glow of natural virtue had deflected attention. Rousseau has to posit an order of individual development to be followed by the ideal educator; this order has to describe the general inclination of individuals and also has to accord with the needs of an ideal society. Rousseau assumes, to begin with, that reason and imagination, defining attributes of humanity, are to be developed only after the physical body and the practical mind have been strengthened and secured; qualities primary for the definition of humanity are secondary in the order of nature.

Emile is to be strong; he is to develop the physical endurance of a primitive, deprived of sleep or food in long walks and rides. Rousseau privileges physical prowess as exemplified in an image of the uncorrupted body of the savages, whose strength, he says, is "subtle (Emile, p. 118), especially in comparison with the clumsiness of European peasants. ${ }^{25}$ Rather than devalue the mind, these passages attempt to show it at one with the body: savages still think with their bodies; they are not alienated from nature or from themselves by the critical, divisive faculty of intellect and its tool, language. This savage integrity of the inhabitants of the New World constitutes for Rousseau a living illustration of his theories and makes it possible for him to imagine the regeneration of the society he despises, but the dissatisfaction he despises is precisely what led to knowledge about these savages. To the explosion of energy that carried Europeans across the ocean, Rousseau opposes the curiously negative virtues of a "natural" integration in the world as it is: "Of all the men in the world, the savages are the least curious and the least bored; all is indifferent to them: they do not enjoy things, but

${ }^{25}$ In the whole passage Rousseau grapples with what looks like the very modern problem of social man's dissociation from his senses and his body; he attributes this self-alienation to the encroachment of society on freedom: peasants are clumsy because their work, though physical, is compelled from the outside, whereas savages, being free, decide upon each act by themselves: "The more their bodies are exercised, the more their spirits are enlightened: their strength and their reason grow together." 
themselves; they spend their lives doing nothing and are never dull" (Emile, p. 271).

The constant activity with which the tutor manipulates Emile's surroundings seeks to restore savage repose, but what it teaches is further activity: the pupil must learn how to cultivate the land, fix a clock or a pair of shoes, shoe a horse, and find his way by the stars, acquiring these abilities at the level at which idealized "Americans" have them and learning to value them like people at an early point of development. ${ }^{26}$ Gradually the model American changes; he is no longer the Canadian who lives by his senses in unmediated contact with nature (Emile, p. 174). Civilization slips in, and he now looks like one of Jean François Marmontel's noble Incas, who, like Rousseau, prize agriculture and manual labor and cannot understand Europeans' aversion to them. The moral point masks the shift in the point of origin, the difference in the definition of American natural man; yet natural man is still American.

A similar shift takes place in Emile's moral education. The virtues of generosity, obedience, trust, and love of honor which should govern the citizen, the man of nature who lives in society, cannot be acquired naturally but must be taught by means of exemplary situations staged by the tutor. More important, Emile also has to be carefully taught compassion, that necessary pivot upon which, in Rousseau's theory, the isolated, independent presocial, and prehistorical savage turns into social and moral man. He has to learn last and from a (socialized) teacher that quality which logically comes first and upon which human society depends. This circularity is important not because it falsifies Rousseau's educational project but because it characterizes his theory of origins as a language, a tool for knowledge, which presents itself as knowledge itself, culture once again passing for nature.

Jean Starobinski claims that Rousseau's enclosed spaces-all these tended gardens in La nouvelle Héloise or Emile where men and women live uncorrupted-hearken back to the story of the Fall and constitute a "transcription of the theological theme of the fall into the language of natural causality" ("La mise en accusation," p. 23). But even if these ideal spaces begin by transcribing the fall into nature, and as if inno-

\footnotetext{
${ }^{26}$ The presence of the clock in this list is amusing. The development of accurate clocks made navigation possible and facilitated the conquest and savaging (in the ignoble sense) of the New World. The clock, moreover, became one of the more commonplace symbols of a mechanized humanity. Does clock repair as a basic skill subvert Rousseau's idea of a "natural" upbringing?
} 
cence were still not enough, Rousseau introduces into each of these figurations of innocence a secular source of almost absolute power dedicated to halting or preventing alienation: the husband, the tutor, the prince. Their right to that power resides in their moral qualities and demands the reasoned, willed acquiescence of their subjects. Wholeness and harmony follow from the proper exercise and due acceptance of this power and determine the quality of life in these enclosures, from physical health to linguistic univocity. Rousseau absorbs into his picture of an unalienated society the desire for an "original" congruence between man and nature and between word and thing whose loss leads immediately to the lie and is the first result of the Fall. As Montaigne maintains in "Des cannibales," savages do not have words for treason or lie and since for them words are still identical with things, do not betray and do not lie. ${ }^{27}$ Thus, to reestablish innocence, to cure the disease of the Fall, it is necessary to regulate language by curtailing some and imposing other forms of discourse. Rousseau attempts to create a discourse, within civilization as he knows it equivalent to that of "savages" as that civilization imagines them. In the process he defines a discourse for exotics, as well as for Emile, functioning in accordance with European notions of exoticism.

Thus, so that he can live in truth and in nature, Emile is kept away from any sort of book knowledge, especially works of the imagination, until his body and character are strong enough to resist them. The semantic and ethical ambiguities of even the simplest fable by La Fontaine are enough to trouble the clear and simple morality upon which Emile's virtues are based and to charge the language of his daily life with resonances that confound its directness and cloud its transparency. In Emile the aim of education is to remove the separation not only between man and nature but also between word and thing. Thus it bans metaphor, following the example of "savages" who live either completely within metaphor-so that it does not function as image but as thing-or completely without it-so that their words correspond directly to things. They also live outside of history, which, like fiction, introduces between word and thing a distorting opacity that impedes

\footnotetext{
${ }^{27}$ Michael Giordano shows Montaigne's efforts to imagine himself out of his own culture and language ("Re-reading Des Cannibales"). In a way, Rousseau was attempting to write the laws for achieving such a retreat into the entirely different. Much of the difficulty in reading Rousseau may be due to the essential contradiction within the task he set himself:
} 
the perception of truth. ${ }^{28}$ This opacity is what Cooper, for instance, tries to erase when he switches from the fictions that made him famous to the transparent account of his nation in Notions of the Americans. This book avoids metaphor; the Leather-stocking tales steep in it the characters who are in closest contact with nature and represent the original American substratum of the nation.

Rousseau, however, refuses to allow for this opacity when he restricts Emile's library to a copy of Robinson Crusoe, which he must read repeatedly, in an abridged edition-"unencumbered by all its claptrap"which includes only the period from the shipwreck on the desert island to Crusoe's rescue (Emile, p. 221). Part of that "claptrap" is the story of Robinson's compulsion to travel and disobedience to his father, his commercial adventures, and his readiness to engage in the slave trade. It is as a story lifted out of history that Robinson Crusoe supplements the reality of the environment the tutor has created for the education of his pupil. Yet it is read as if it were a historical account of survival in nature, completely and accurately mimetic, as if nothing set in a world as yet deprived of a fictional overlay could be fiction.

The programmatic exclusion of fiction from the laboratory-garden where Rousseau conducts his experiment in natural education is one step in the re-creation of that world. But though the tutor draws his views of where to begin the construction of a new man for a new society from what he knows of Hurons and Hottentots, the society into which he educates his pupil is that of small, independent landholders who ideally would not want to leave their bit of soil. Emile is not allowed human contacts that would lead to speculation; he is limited to those that bring unmediated, practical benefits: a wet nurse for the human milk and cuddles necessary to his infant health; a laborer to teach him that work is the foundation of property; a shoemaker and a smith to teach him their trades; selected urchins to teach him to compete in races

\footnotetext{
${ }^{28}$ Anthony Pagden, in "The Savage Critic," reminds us of the philosophical and ethical conclusions at which European thinkers arrived on the basis of the assumption that "savages" had no words for lie, treason, avarice, envy (Montaigne, "Des cannibales," p. 243), or even God (Manuel da Nóbrega, "Cartas," p. 62). The editors of Rousseau's Oeuvres complètes quote Charles Marie de la Condamine's Relation abrégrée $d u$ voyage fait à l'intérieur de l'Amérique méridionale (Paris: Pissot, 1745), pp. 51-54, to the effect that the languages of the Amerindians lack the words for time, duration, space, being, substance, matter, body, as well as for virtue, justice, freedom, recognition, ingratitude. Here the point seems to be that they lack the means for abstract thought, rather than for the expression of particular vices. The general idea however is that the lacunae in the vocabularies of savages are proof of their moral or intellectual capacities, of their difference.
} 
and to be as magnanimous in victory as is appropriate for his social class, and Crusoe to teach him to survive in pure nature. In this glide from nature through property to class one can see at work the process that transformed savage Hurons into noble Incas, that makes morality wander from the unalienated body into unalienated language, that always defines noble savagery according to an unacknowledged base of civilization. With writing, however, distinctions seem at first clearer: the savage is literal, and Emile must avoid La Fontaine's "Fox and the Raven," ethically as artificial and distorted as its syntax; a child has no business understanding either because understanding is already a sign of corruption. La Fontaine makes the child clever instead of good and teaches that moral corruption is inevitable, that the idle exercise of the imagination is laudable, that words have multiple meanings, and that the relation between the text and the extratextual is mediate. ${ }^{29}$ But a transparent Crusoe is not a text, and its transparency confers the same status on Emile; it can thus uphold the authority of Emile and elide the manipulations of the tutor, Rousseau's pedagogical self. The primitivism described by Daniel Defoe (whose name Rousseau never mentions) is presented as ontologically equivalent to the civilization for which Emile is being prepared. At least at this point in Rousseau's argument, however, primitivism is also instrumental and temporary. Emile should learn from Crusoe how to be practical and from the primitive world of the book how to be self-sufficient for as long as self-sufficiency is practical. Robinson Crusoe is given to him at an early age because its lessons are basic: it teaches Emile to value a hardware store more than a trendy boutique (p. 213) and by limiting his experiences, it serves, like the Hurons, as an introduction to thinking about the origins and perfection of language, society, and writing.

In Defoe's island Rousseau sees a precedent of his own laboratory for civilization. Though he constantly reminds his readers that Emile's pedagogical garden is as fictional as the pupil and the tutor, Rousseau uses Robinson Crusoe to blur the line between fiction and documentary, to mediate between his own text and the extratextual world. What matters for the present argument, however, is that the New World becomes the space of his laboratory, the medium in which his theories will grow strong enough to be transplanted into the corrupted world of civil society without succumbing to its vices. In using Defoe's fiction as if it were

${ }^{29}$ Joan DeJean analyses Rousseau's quarrel with La Fontaine's fables mainly in psychological terms, focusing on the pedagogical relationship, rather than on the question of language ("The Law(s) of the Pedagogical Jungle"). 
one more travelogue, Rousseau constructs a relay over which the initial discourse of the New World changes registers from factual to moral and is readied for retransmission to the New World.

Criticism of Rousseau's notion of natural man has shown the ambiguity of both its definition and its valuation, but even if it is no longer read as ethnographically and archaeologically accurate or as an ethical model for members of a civil society, it can still be seen as the index of how civilization thought of itself and a compendium of the virtues it would be prepared and equipped to preserve. ${ }^{30}$ But the misunderstanding of Rousseau is as much a fact in the history of ideas as is his reasoning well understood. ${ }^{31}$ The conventional image of the noble savage, documented in fiction and in what today we call "faction," quired the status of extraliterary reality and shaped that reality. When Chateaubriand disavows the noble savage (Atala, Weil ed., p. 8), he shares his misreading of Rousseau with his audience; despite his criticism of Rousseau, his depiction of Amerindians both in his fiction and in his memoirs fixes that image and gives it a denser reality than the cliché could otherwise have achieved.

Primitivism, however, that state of potentiality preceding the actualization of civil society, is a condition defined not only ontologically and juridically but also ethically and genetically. Asocial man, as Rousseau

${ }^{30}$ Jean Terrasse lists the characteristics of what he calls the contenu of the "myth" of natural man in a clear and concise discussion (Jean-Jacques Rousseau et la quête de l'âge $d^{\prime}$ 'or, pp. 59-60). Cranston characterizes the "man of nature," or "original man," of the Discours sur l'inégalité as Rousseau's response to social and political realities of his time, to the ideas of Locke and Hobbes, and to his own life experiences-that is, as criticism conditioned by the world in which Rousseau lived (chap. 15, "On the Origins of Inequality").

${ }^{31}$ Lovejoy believes that "the notion that Rousseau's Discourse on Inequality was essentially a glorification of the state of nature, and that its influence tended wholly or chiefly to promote 'primitivism' is one of the most persistent of historical errors." He rectifies this misreading by reference to specific passages in the Discours and to its relation to contemporary writings of Hobbes, Diderot, Locke; he also quotes an extended passage of W. A. Dunning, History of Political Theories, 3:8-9, to document the persistence and respectability of that misreading (p. 14). Jean Terrasse discusses some of the internal reasons for the multiplicity of readings, since "nature ... . [is] at the same time the collection of historical manifestations of human consciousness and the principle which produces them, and the knowledge of which allows the philosopher to fill in by conjecture the lacunae of history" (p. 69).

${ }^{32}$ Marmontel, whose Incas was part of Rousseau's intellectual environment, claims for his work the truth of facts as they were reported by Bartolomé de Las Casas, the authority of a proper ethical stand, and the persuasiveness of a complementary imagination: "It is therefore less the tissue of a fable than the thread of a simple account, of which the entire substance is historical, and to which I have added a few fictions compatible with the truth of facts" (Les Incas, pp. xxiv-xxxv). 
sometimes conceives of him, is also amoral. ${ }^{33}$ His desire cannot meet with judgment or resistance, because it is all directed toward the satisfaction of basic needs for food, shelter, and occasional sexual contact. ${ }^{34}$ For the Rousseau of the treatises, sexual contact itself is simple and direct, and since individualization appears only at the moment of socialization, any female is good for any male: only the function of reproduction matters and the complex of social rules governing the proper choice of mates is unnecessary. Thus Rousseau disposes of the entire charged matter of sexual morality in the early stages of individual or social development, with consequences, as it must happen, for the view of morality in "primitives" as encountered in other climes. Sexual amorality is difficult to imagine: it tends to flip into immorality, into license, for much of the complex of regulations governing the life of social groups revolves around the allocation of sexual partners, and many of its strongest laws (according to Lévi-Strauss, precisely those that constitute the foundation of societies and separate culture from nature) detail forbidden pairings. ${ }^{35}$

It is a testimony to the importance of regulations for the proper allocation of partners that in the fiction of the New World, whether written by Europeans or by the first writers of the newly independent nations,

${ }^{33}$ Marc Plattner wrestles with the ethical implications of Rousseau's possible assumption that "natural man is just another animal" (Rousseau's State of Nature, pp. 63-64). In his introduction to $\mathrm{Du}$ contrat social, Ronald Grimsley states that, for Rousseau, primitive man was animallike, nonmoral, happy, innocent, independent (p. 9). Grimsley then follows the logical process by which arose morality as well as the alienation consequent on the development of society as it came to be in Europe. But Rousseau himself explains: "It seems at first that since men in that state [of nature] had among themselves no kind of moral relationships nor any common duties, they could be neither good nor evil and had neither vices nor virtues except insofar as one considers vices in the individual those qualities that can harm his survival and virtues those that foster it" (Discours sur l'inégalité, p. 152).

34 "L'homme sauvage" desires only food, woman, and rest; he fears hunger and pain; he knows no death, having neither prescience nor memory (Discours sur l'inégalité, p. 143).

${ }^{35}$ One of the intriguing aspects of Rousseau's discussion of the relation between sexual morality and social organization is his separation of the natural function of procreation from the social institution of marriage. In the Second discours he quotes a long passage from Locke's Second Treatise of Government (1619), which argues for the "naturalness" of the institution of the family (chap. 7, sec. 79-80). Rousseau objects that in the state of nature a male is not aware of either conception or gestation, that neither male nor female need be aware of the connection between cohabitation and gestation; forming a family is a consequence of choice, conditioned by freedom, not natural necessity (Discours sur l'inégalité, pp. 214-18). For Lévi-Strauss's discussion of the relation between the incest taboo and the origin of culture, see Les structures élémentaires de la parenté, p. 9. 
these regulations, whose absence had been one of the more dramatic traits of Rousseau's characterization of the state of nature, became pivotal points in the formulation of national consciousness. The fiction of the New World almost invariably touches on the problems of either incest or extreme exogamy (in marriages between original inhabitants of the Americas and European settlers and conquerors), as if it were mapping the boundaries of a definition of culture. On one hand, it tries out the extremes of primitivism and decadence which touch in the theme of incest, the act that affirms the absence of marriage rules; on the other hand, it posits extreme cases of exogamy, which mark the possibility of association with what appears as an absolute other, a partner who shares with the European protagonist only those traits defined as independent of cultural condition, as "natural." The incest plot questions the morality of conquest by charging the conquering culture with a breach of rules fundamental to its very classification as a culture, before matters such as its right to action and its superiority are even raised. The exogamy plot touches on the process of conquest, raising the possibility that European mastery of the New World is conditioned upon the embedding of the conqueror in the conquered and the blurring of a difference that affirms European identity and should continuously signal and validate conquest.

From the beginning, the discourse of sexuality had been part of the discourse about the New World, and when he informs his readers of the correlation between the state of savagery, on one hand, and early puberty and strong sexuality, on the other, Rousseau picks up on information given by various travelers as well as following the logic of his own argument about the characteristics of "savages. ${ }^{\prime 36}$ Like his assertion that sexual behavior in the state of nature is indiscriminate, his discussion of the sexuality of savages not only contributes an alluring color to the depiction of conditions in the New World, whence he takes most of his examples, but also defines its dangers for civilization, civility, and morality, which are based on the regulation of the libido and on the proper distribution of females.

Living for and by the satisfaction of simple desires coterminal with each individual's existence, man in Rousseau's state of nature has no memory and no history. His world begins anew at every dawn, and he is never separated from the needs and pleasures of one day by the

\footnotetext{
${ }^{36}$ Book 4 of Emile discusses sexuality in adolescence and in primitive peoples; see
} especially pp. 251, 247, 249. 
memory or fear of another. ${ }^{37}$ Like the implications of his thought in terms of the marriage plot, this savage ahistoricity can be made into a New World asset, but the assertion of value is seldom made upon a negation. As it developed in the New World, the choice was not whether to value the presence or the absence of history but which of two different histories to value. Just as Rousseau selected aspects of New World ethnography to validate his theories, so the New World selected aspects of Rousseau's theories to validate its self-definition and fabricate an identity and a history with bits and pieces of what was considered important in the metropoles, like Frankenstein fabricating a new man.

Since, like Rousseau, the New World saw itself as creating a new society and a new citizen for it, his works provided a manual and also an argument about what underlies the task. Du contrat social and Emile posit that society and man-in-society cannot be taken for granted: in searching for their origin, Rousseau also makes them subject to choice and thus contingent. Julie's and Emile's gardens result, by definition, from a return to nature by man formed within an alienating society. Like Defoe's island, Rousseau's gardens are the product of a salvage operation, a bricolage with bits of European civilization saved from shipwreck. For Rousseau too, nature does not in the end suffice as a fundamental value: in place of Robinson's Bible, he inserts in Emile the "Creed of the Savoyard Priest," the metasystem of beliefs that originate the moral certainty upon which he plants his garden. And thus Emile is prepared to become not a man in the state of nature but "nature as reconstructed by a rational being. ${ }^{\prime \prime 8}$ Emile is removed from society and history so he can occupy his rightful place in society and fulfill the historical obligations of his class as landowner and head of a family; his separation from history leads to his retrieval of authentic time and an authentic self.

One can see how Rousseau's transformation of the received discourse of the New World became useful when the New World prepared to establish a willed identity in the space between redemptive nature and productive civilization. Just as Rousseau furnished arguments for different political systems, he also furnished grounds for different and con-

\footnotetext{
${ }^{37}$ Baczko sees this animallike existence as another side of the new sensibility Rousseau introduces, a matter of psychological, rather than social or historical alienation (pp. 13-14). This may be, as Baczko himself suggests further on (p. 19)-an insight shaped as much by the circumstances of that critic's situation as by the thought he analyzes. ${ }^{38}$ The observation is that of Ingrid Kislink, whose view of these gardens differs from mine. See "Le symbolisme du jardin," p. 330.
} 
tradictory approaches to the topics through which self-definition was sought. He returned the gift of the New World vocabulary enhanced in fiction, philosophy, and political science. In the forests of the New World, for instance, to seek man removed from history was to perfect Emile with Indians, whose ahistoricity did not have to be artificially induced, who did not have to be removed from society since they could be-and often were-defined as presocial. The figure of a noble savage, regardless of its fidelity to the Rousseauean concept, could be used to paint an American native most agreeable to European fantasies of Eden recovered and the golden age reconstructed. Some of his virtues- fidelity to friend, vengefulness to foe, capacity for constant love-were completely out of character for Rousseau's natural man, since they defined social relationships, but in the fiction of the New World, they combined freely and even necessarily with the more properly "natural" virtues of endurance, strength, and familiarity with the forest, which could also be read in Rousseau. The combination melded in fictional inhabitants of the New World the best qualities of unspoiled nature and a renewed social man. In this guise of examples of virtue and redemption defined by and external to European civilization the Amerindians of early New World literature came to function as a metonymy for all the positively characterized inhabitants of the colonies and to represent the possibility of creating there a redeemed society.

At the same time, Rousseau can account for the new nations' continued intervention in the original garden. The Discours sur l'inégalité implies the presence of an unnamed power lurking in the interstices of a discourse that purports to be entirely about neutral nature. Not only does Rousseau claim that he cannot imagine an unmediated process for the acquisition of language, the indispensable instrument for socialization (p. 151), ${ }^{39}$ but he also introduces a telltale passive voice at the very point where he first proposes pity, or compassion, as the basis upon which it becomes possible to leap from the absolute freedom (resulting from the absence of desire) of natural man to the social organization that permits the creation of civilization. Compassion, he says, "was given" to man (p. 154) to soften the ferocity of self-interest which would have permitted neither the propinquity necessary for the formation of a society nor the more benevolent feelings toward others which he saw as the only positive justification for social life. The passive voice intro-

${ }^{39}$ At this point Rousseau gives up on part of the problem of language and invites others to decide whether it or socialization came first. 
duces an unnamed actor into the impersonal field of rational discourse, an agent into the process of natural development. Although the primitives that for Rousseau exemplify man without society are specifically defined not as properly natural but only as closer to nature than the Europeans who study them, conquer them, and use them as examples, it is still logically necessary to posit an intervention by some more socially developed entity (in Emile, the tutor) before these natural men are able to reach full socialization. The passage is not necessarily a happy one. In fact, Rousseau sees the intermediary stage as particularly unhappy, a state in which a new system of uncontrollable and unquenchable desires is overlaid on an older, though primitive, contentment. It is very much like the state in which Chateaubriand shows Chactas of Atala, and it constitutes one possible justification for the construction of political entities on the substratum of a "natural" landscape and population of the Americas.

The "noble savage" as a shorthand for the ideal of the virtuous primitive persists in modern characterizations of early modern authors, shorn of its more complicated connotations and formed into a systematic and culture-bound misreading of Rousseau. Roy Harvey Pearce and George D. Painter title chapters of their studies of Cooper and Chateaubriand by that name, characterizing the national subject matter of the former and buttressing the authority of the latter. Nevertheless, a "correction" of this misreading would falsify, if not Rousseau's thought, then the common references to it. Rousseau speaks of the savages with nostalgia and values them positively; that he promises an even higher value for the restored naturalness of the ideal society was safely disregarded by those who used his terms to create a system of oppositions fundamental to the discourse of the New World.

The vocabulary-generating force of Rousseau's hypotheses defied the contradictions of his premises. ${ }^{40}$ The mysterious capacity for socialization of his natural man, which permits the essential shift from the state of nature to that of society, ${ }^{41}$ generated a space for the fiction of new

\footnotetext{
${ }^{40}$ In a somewhat different context, Baczko notes that history took charge of some of the meanings of Rousseau's work (p. 50).

${ }^{41}$ Pitié, or the capacity to put oneself in another's place, is the positive form of a basis for social relationships; it is a given. Amour-propre, or the undue preoccupation with the opinions of others, is the negative or corrupt form of attention to others. Rousseau opposes it to amour de soi, self-respect, which could be said to mark independence from the other. Charvet opposes it to pitié itself and considers this opposition one more of the essential contradictions at the root of Rousseau's idea of man's capacity for social life (pp. 12, 17-19). Charvet thinks these contradictions invalidate Rousseau's
} 
polities. The indeterminacy in the definition of the man of nature provided a semantic space where a natural New World opposed and redeemed denatured Europe, and promised to cure, within society, society's ills. Thus the positive valuation Rousseau attributes to his imprecisely defined man of nature created, together with a denotative vocabulary, one of values. By marking the primitive as desirable and the worth of the social as, at best, doubtful, Rousseau opened the possibility for a positive valuation of the foundations on which the new American nations built their civil societies; but he also provided terms in which the new nations could couch their necessary attempt to leave the state of nature and, as fully constituted societies, claim the right to participate in the political, cultural, and economic affairs of a world economy of goods and ideas.

Rousseau's concept of natural man gives theoretical and philosophical density to the factual accounts of the early voyagers but places the peoples of the New World in the intellectual service of European thought. At the same time, natural man, without history or language, without society or desire, invites crowds of qualities into these empty conceptual spaces. A traditional iconography of New World inhabitants draws up his features and adornments; the ancients contribute civic virtues, and natural man, transformed into the noble savage, becomes also a starting point from which the discourse on origins questions European political institutions and allows power and morality to be seen as no longer "natural," as created and modifiable by human will. ${ }^{42}$ And thus natural man travels back from the New to the Old World.

Rousseau's effect on an already established discourse on origins, history, power, and the limits of desire becomes clearer as one considers another well-received work that became the model for a treatment of the New World in its own time. Marmontel's influential book Les Incas recounted the conquest of Peru as tragic history. His Incas are as noble a people as were the ancient Romans. Theirs is a developed and reasonable society, whose institutions, though imperfect, are open to improvement by a virtuous representative of Christianity, a European aristocrat by birth and character. The civil war that erupts among the Incas just

thought, but they could also be seen as generating various forms of social and literary discourse, from autobiography to satire.

${ }^{42}$ Baczko notes the subversive character of the question about origins: "Whatever version it appears in, the search for 'origins' is equivalent to a call into question" of that which is taken for granted, whether in principles of government, justification for the distribution of power, or a definition of human nature which would explain them (pp. 61, 62-64). 
at the time of the European invasion and the presence of bandits, rogues, and religious fanatics among the invading Spanish precipitate the tragedy of conquest and destroy the opportunity for mutual redemption by allowing the worst sort of European tyranny to replace the best of American indigenous civilizations. ${ }^{43}$ But for Marmontel the tragic conflict does not pit nature against civilization; on the contrary, it exposes the breach that necessarily splits civilization-not savageryinto a virtuous and an evil side. The play of oppositions takes place within the field of civil society, which contains all recognizably human life. But the reformist impulse of Les Incas was abandoned, and despite its initial success, Marmontel's did not become the model for a fiction of the New World, which structured itself not around an opposition between good and evil within civil society but around the opposition between the social and the extra-or pre-social, characteristic of a criticism of society based on a meditation about origins. The return to origins implicitly promises regeneration, but the concept of the original flickers on the limits of the imaginable. The New World, then, furnished the images in which that concept could become conceivable, and the fiction that resulted from that use put the concept in motion and explored the consequences of the opposition between the cultural and the natural and the demands placed by culture on nature.

${ }^{43}$ Les Incas is dedicated to the king of Sweden and introduced with a diatribe against fanaticism in general and Spanish atrocities in particular, as described by Las Casas; it thus indirectly attributes errors in civilizing savages to the improper distribution of power among European states, which assigned the New World to an incompetent civilizer. That he does not doubt the appropriateness of the civilizing effort itself can be seen in his assertion, through an epigraph by Fénélon, that men should be led toward God and king by a "gentle persuasion," and in his definition of the Indians as "weak" and, in a Rousseauean turn, "without desires, almost without needs" (pp. xiv, xvi-xxii). 